\title{
Raman Micro Spectroscopy Study of the Interaction of Vincristine with A549 Cells Supported by Expression Analysis of bcl-2 Protein
}

Haq Nawaz

Technological University Dublin

Amaya Garcia

Technological University Dublin

Aidan Meade

Technological University Dublin, aidan.meade@tudublin.ie

See next page for additional authors

Follow this and additional works at: https://arrow.tudublin.ie/biophonart

Part of the Other Analytical, Diagnostic and Therapeutic Techniques and Equipment Commons, Pharmaceutical Preparations Commons, Physics Commons, and the Therapeutics Commons

\section{Recommended Citation}

Byrne, H. J. (2013) Raman micro spectroscopy study of the interaction of vincristine with A549 cells supported by expression analysis of bcl-2 protein", Analyst, 138, pp.6177-6184. doi: 10.1039/c3an00975k

This Article is brought to you for free and open access by the DIT Biophotonics and Imaging at ARROW@TU Dublin. It has been accepted for inclusion in Articles by an authorized administrator of ARROW@TU Dublin. For more information, please contact arrow.admin@tudublin.ie, aisling.coyne@tudublin.ie,gerard.connolly@tudublin.ie. Funder: HEA

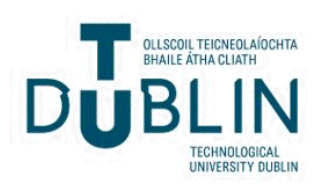




\section{Authors}

Haq Nawaz, Amaya Garcia, Aidan Meade, Fiona Lyng, and Hugh Byrne

This article is available at ARROW@TU Dublin: https://arrow.tudublin.ie/biophonart/6 


\title{
Raman micro spectroscopy study of the interaction of vincristine with A549 cells supported by expression analysis of bcl-2 protein
}

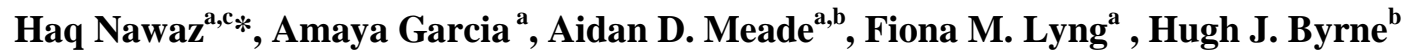 \\ a DIT Centre for Radiation and Environmental Science (RESC), Focas Research Institute, Dublin Institute of Technology, Kevin Street, \\ Dublin 8, Ireland \\ b. Focas Research Institute, Dublin Institute of Technology, Kevin Street, Dublin 8, Ireland. \\ ${ }^{c}$ National Institute for Biotechnology and Genetic Engineering (NIBGE), P.O.Box 577, Jhang Road Faisalabad, Pakistan. \\ ${ }_{10}$ *Corresponding Author $(\mathrm{a}, \mathrm{c})$ : \\ Haq Nawaz, \\ DIT Centre for Radiation and Environmental Science (RESC), Focas Research Institute, Dublin Institute of Technology, Kevin Street, \\ Dublin 8, Ireland. \\ \& \\ 15 National Institute for Biotechnology and Genetic Engineering (NIBGE), P.O.Box 577, Jhang road Faisalabad, Pakistan.
}

$\underline{\text { haq.nawaz@dit.ie }}$

Received (in $X X X, X X X)$ ) Xth $X X X X X X X X X 200 X$, Accepted Xth $X X X X X X X X X 200 X$

${ }_{20}$ First published on the web $X$ th $X X X X X X X X X 200 X$

DOI: 10.1039/b000000x

\begin{abstract}
Understanding the interaction of anticancer drugs with model cell lines is important to elucidate the mode of action of these drugs as well 25 as to develop cost effective and rapid screening methods. Raman spectroscopy has been demonstrated to be a valuable technique for high throughput, noninvasive analysis. The interaction of vincristine with a human lung adenocarcinoma cell line (A549) was investigated using Raman micro spectroscopy. The results were correlated with parallel measurements from the MTT cytotoxicity assay, which yielded an $\mathrm{IC}_{50}$ value of $0.10 \pm 0.03 \mu \mathrm{M}$. The Raman spectral data acquired from vincristine treated A549 cells was analysed to understand its interaction with the nucleus in the cell and elucidate DNA intercalation. The dose dependent spectral changes in the 30 nucleus are analysed by PLS-Jack knifing for the identification of the more significant changes associated with the mode of action of the drug. Results are correlated with a similar dose dependent expression analysis of the bcl-2 protein, an anti-apoptotic protein associated with DNA damage, in the vincristine treated A549 cells using flow cytometry. The results indicate the co-existence of two modes of action, microtubule binding at low doses and DNA intercalation at high doses.
\end{abstract}

\section{${ }_{35}$ Introduction}

The in vitro study of the interaction of anticancer drugs with mammalian cells is important to elucidate the mechanisms of action of the drug on its biological targets 40 and thereby maximise efficacy. Cancer cell lines can be a good model to study the effects of these anticancer agents and such in vitro studies are in accordance with the EU policy of Reduction, Replacement and Refinement (RRR) of the protection of animals used for experimental and ${ }_{45}$ scientific purposes (Directive 2010/63/EU). Another concern is the requirement of a non-invasive, cost effective, rapid screening technique which can analyse the samples, ideally without any labelling. Raman micro spectroscopy potentially provides these benefits ${ }^{1}$. In ${ }_{50}$ addition, Raman spectroscopy can provide high content information, as it can examine spectral changes in the cell membrane, cytoplasm and nucleus of the target cells simultaneously and can differentiate the biochemical interaction of external agents with the cell from its ${ }_{55}$ physiological response $^{2,3}$.
The potential of confocal Raman micro spectroscopy (CRM) for the analysis of biological tissue ${ }^{4}$ and the effect of external agents on the cell ${ }^{5-9}$ has been demonstrated. Moreover, the technique, with its counterpart Fourier ${ }_{60}$ transform infrared (FTIR) micro spectroscopy, is being used to explore sub-cellular biochemical structure, as demonstrated by its use in studies investigating the action of various agents on biological macromolecules as well as their interaction with cancer cells $\mathrm{s}^{1-3,10-17}$.

${ }_{65}$ The use of CRM in studying the biochemical effects of established, commercially available anticancer drugs may be helpful therefore in order to validate its use for the evaluation of the novel anticancer agents. To this end, such an approach was demonstrated for the action of cis-platin 70 with lung cells in vitro ${ }^{2,3}$. The study utilized multivariate regression and feature selection techniques to correlate spectral changes with drug dose and cell viability, as measured using a standard cytotoxic assay.

A proposed primary mode of action of vincristine is 75 through its binding to tubulin monomers in the cytoplasm, which leads to a change in the dynamics of the microtubule assembly and prevention of the formation of bi-polar spindles ${ }^{18}$, necessary for the proper segregation of the duplicated chromosomes and ultimately cell division. 
Additionally, however, vincristine has been reported to interact directly with DNA in acellular studies, as observed using techniques such as Atomic Force Microscopy ${ }^{19}$, Fluorescence image microscopy ${ }^{20}$ and FTIR spectroscopy ${ }_{5}^{21}$, which indicate that it acts as an intercalator. The combined evidence raises the question as to whether vincristine causes cell death only by disturbing the dynamics of the microtubule assembly or whether the DNA damage caused by this anticancer agent also 10 contributes to its efficacy.

The purpose of this study is to further elucidate the interaction of the drug on a cellular level, as well as the cellular response pathways, using CRM to characterise biochemical changes on the subcellular level. To support 15 the spectroscopic investigation, the expression of bcl-2 protein as a result of vincristine treatment is explored using flow cytometry. Bcl-2 is an anti-apoptotic protein which is generated as a direct result of DNA damage, and is thus involved in the regulation of cell death and serves as an 20 indicator of genotoxic stress to the cell 22,23 . The comparison of the observations of changes to the Raman signatures of nucleus of the A549 cells as a result of vincristine exposure as compared to the unexposed control, as well as the changes in the expression profile of bcl-2, 25 may lead to elucidation as to whether DNA damage contributes to the mode of action of this anticancer agent.

\section{Experimental ${ }_{30}$ MTT assay}

Vincristine was purchased from Sigma Aldrich, Ireland, in the form of vincristine sulphate (V8388) and a stock solution was prepared in distilled water. Working solutions were prepared in the cell culture media.

${ }_{35}$ MTT was obtained from Sigma Aldrich, Ireland. The MTT assay was performed in triplicate according to a method reported previously ${ }^{24}$ with a slight modification. The exposure of A549 cells to vincristine was done for 96hours, over a wide range of concentrations $(0.01-10 \mu \mathrm{M})$ to ${ }_{40}$ establish the half maximal inhibitory concentration $\left(\mathrm{IC}_{50}\right)$ and the appropriate range over which to conduct the analysis.

The MTT measurement protocol was as follows. Cells were cultured in 96-well plates (Nunc, Denmark) at a ${ }_{45}$ density of $2 \times 10^{3}$ cells per well in Dulbecco's Modified Eagle Medium-F12 (DMEM) with all the supplements as listed above. After 24 hrs of initial cell attachment, the plates were washed with $100 \mu \mathrm{l} /$ well phosphate buffered saline (PBS) and were treated with varying concentrations ${ }_{50}$ of vincristine in the range of $0.01 \mu \mathrm{M}-10 \mu \mathrm{M}$ (including a separate unexposed control sample). Following a 96-hour exposure period, the cells were rinsed with PBS and $100 \mu 1$ of fresh medium (without supplements) were added to each well. A volume of $10 \mu \mathrm{l}$ of MTT $(5 \mathrm{mg} / \mathrm{ml})$ prepared in
${ }_{55}$ PBS was then added to each well and the plates were incubated for $3 \mathrm{hrs}$ at $37{ }^{\circ} \mathrm{C}$ in a $5 \% \mathrm{CO}_{2}$ humidified incubator. After this incubation period, the medium was discarded, the cells were washed with $100 \mu \mathrm{l}$ of PBS and $100 \mu \mathrm{l}$ of Dimethyl Sulphoxide (DMSO) were added to ${ }_{60}$ each well to extract the dye. The plates were then shaken 240 times per minute for $10 \mathrm{~min}$ and the absorbance was measured at $570 \mathrm{~nm}$ using a micro plate reader (Tecan Genios, Grodig, Austria). Six replicate wells were used for each exposure.

65

\section{Raman micro spectroscopy}

In this work, CRM was conducted with a Horiba JobinYvon, LabRam HR800 instrument using a $785 \mathrm{~nm}$ laser as source. Spectra were taken in the range from $600 \mathrm{~cm}^{-1}$ to $701800 \mathrm{~cm}^{-1}$ with a confocal hole diameter of $100 \mu \mathrm{m}$. A x100 water immersion objective was used to focus the laser on the sample, immersed in $0.9 \%$ saline, yielding a spot size of $\sim 1 \mu \mathrm{m}$.

For CRM, cell samples were cultured on quartz substrates 75 according to a protocol outlined elsewhere 9 . Briefly, quartz coverslips were coated with a $2 \% \mathrm{w} / \mathrm{v}$ gelatin-water solution and maintained at $4{ }^{\circ} \mathrm{C}$ for $6 \mathrm{hrs}$ to allow polymerization of the gelatin on the substrate. Subsequently, $2.5 \times 10^{3}$ A549 cells were attached to the 80 substrates for a 48 hour period, and were exposed to vincristine concentrations in the range of $0.01 \mu \mathrm{M}-10 \mu \mathrm{M}$ for a 96-hour period (together with a non-exposed control sample). After the exposure period, the cells were fixed in $4 \%$ formalin for 10 minutes and were stored in $0.9 \%$ ${ }_{85}$ physiological saline solution at $4{ }^{\circ} \mathrm{C}$ until the Raman analysis was performed ${ }^{25}$. All samples were prepared in triplicate.

For spectral acquisition, the laser power was approximately $70 \mathrm{~mW}$ at the sample. Spectra were taken in 90 the range from $600 \mathrm{~cm}^{-1}$ to $1800 \mathrm{~cm}^{-1}$ with a confocal hole diameter of $100 \mu \mathrm{m}$. A $\times 100$ water immersion objective was used to focus the laser on the sample, immersed in $0.9 \%$ saline, yielding a spot size of $\sim 1 \mu \mathrm{m}$. Multiple spectra were recorded from the nuclear portion, visually 95 identified using the optical microscope of the instrument, of a total of 60 cells at each exposure level. The point spectra were recorded from the cell nuclei of the sixty different A549 cells for control as well as exposed samples.

100

\section{Data analysis}

All spectral analysis was performed in the Matlab 7.2 (The Mathworks Inc.) environment employing the PLS Toolbox 105 5.0.3 (Eigenvector Research, Wenatchee, WA) and algorithms developed in-house. Subsequently, the spectra were smoothed with a Savitsky-Golay filter (order 5, 13 point window), and the quartz signal background was subtracted using algorithms developed in-house. Prior to 
analysis, the spectra were also vector normalized and a fifth order polynomial was fitted to the spectra to remove any residual spectral baseline. Outlying spectra were removed using Grubb's filtering ${ }^{26}$.

${ }_{5}$ PLS Jack-knifing was employed as a multivariate feature selection technique ${ }^{27-29}$. The PLS regression algorithm seeks to develop a model that relates the spectral data $(X$ matrix) to a series of targets ( $Y$-matrix, e.g. concentration of reaction product or analyte) according to the equation ${ }_{10} Y=X B+E$, where $B$ is a matrix of regression coefficients and $E$ is the regression residual. The Y-matrix here consisted of values of the concentration of vincristine to which the cells were exposed, or the measured level of cell viability from the MTT assay. The PLS Jack-knifing 15 method developed by Westad and Martens was then used to determine the spectral features that were statistically significant at a particular level of confidence using $\mathrm{t}$ testing of the regression coefficients, $B{ }^{29}$. The Raman band assignments used in interpretation of the spectral 20 features were taken from the literature ${ }^{9,15,30-32}$.

\section{Flow cytometry}

For the culture of A549 cells, the materials and protocols ${ }_{25}$ used were the same as those described above for Raman spectroscopy measurements. The bcl-2 antibody labelled by FITC with an IgG1 isotype control was purchased from BD biosciences (BD 556357). The cytoperm/ cytofix fixation/ permeabilization kit was purchased from BD 30 biosciences (BD 554714).

The A549 cells were cultured in tissue culture flasks (Nunc, Denmark) at a density of $1 \times 10^{5}$ cells in DMEMF12 medium with all the supplements as described earlier. After $24 \mathrm{hrs}$ of initial cell attachment, the plates were 35 washed with PBS and were treated with varying concentrations of vincristine in the range from $0.01 \mu \mathrm{M}$ $10 \mu \mathrm{M}$ (including a separate unexposed control sample). Following a 96-hour exposure period, the cells were trypsinised and collected in an Eppendorf, $1 \times 10^{6}$ cells per ${ }_{40}$ sample. The cells were washed twice with ice cold Dulbecco's Phosphate-Buffered Saline (DPBS) buffer (containing protein and $\mathrm{NaN}_{3}$ ), gently resuspended and centrifuged (250-300 g). The fixation buffer $(250 \mu \mathrm{l})$ was added to each sample, and the process was followed by ${ }_{45}$ gentle pipetting and incubation for 30 minutes at $4{ }^{\circ} \mathrm{C}$. The fixed cells were washed and suspended in the stain buffer. This was followed by the addition of $100 \mu$ l of the permeabilization buffer and incubation for 15 minutes at room temperature. The samples were then washed twice 50 with $1 \mathrm{ml}$ of the perm wash buffer and centrifuged at 250$300 \mathrm{~g}$ for 5 minutes at $4{ }^{\circ} \mathrm{C}$, and the cells were suspended in $50 \mu$ of the perm wash buffer and the diluted antibody was added. This was followed by incubation of the samples for 60 minutes, on ice and in the dark. Then cells

55 were washed twice with the perm wash solution to remove the unbound antibody. The tubes were inverted and blotted to remove the supernatant. The samples were resuspended in stain buffer and analyzed by flow cytometry.
The expression analysis of the bcl- 2 protein in A549 cells ${ }_{60}$ due to the action of the vincristine was performed using a Partec Flow Cytometer (Partec UK Limited, U.K.) and the data analysis was performed using Summit software (Version 4.3, DAKO, Denmark).

\section{${ }_{65}$ Results $\mathrm{IC}_{50}$ for vincristine}

The MTT results for the cytotoxicity measurement of vincristine in A549 cells are presented in Figure 1. The ${ }_{70}$ level of viability in each sample was normalised to that of the control sample. The Inhibitory Concentration $\left(\mathrm{IC}_{50}\right)$ value was derived from the data by a fit of the Hill equation, $\mathrm{f}(\mathrm{x})=\min +(\max -\min ) /\left(1+\left(\mathrm{x} / \mathrm{IC}_{50}\right)^{\wedge} \mathrm{n}\right)$ and found to be $0.10 \pm 0.03 \mu \mathrm{M}$. The primary purpose of the MTT ${ }_{75}$ assay was to determine the exposure range over which the maximum variation occurs in the cellular response, and thus the optimum range to probe the associated changes to the spectral response.

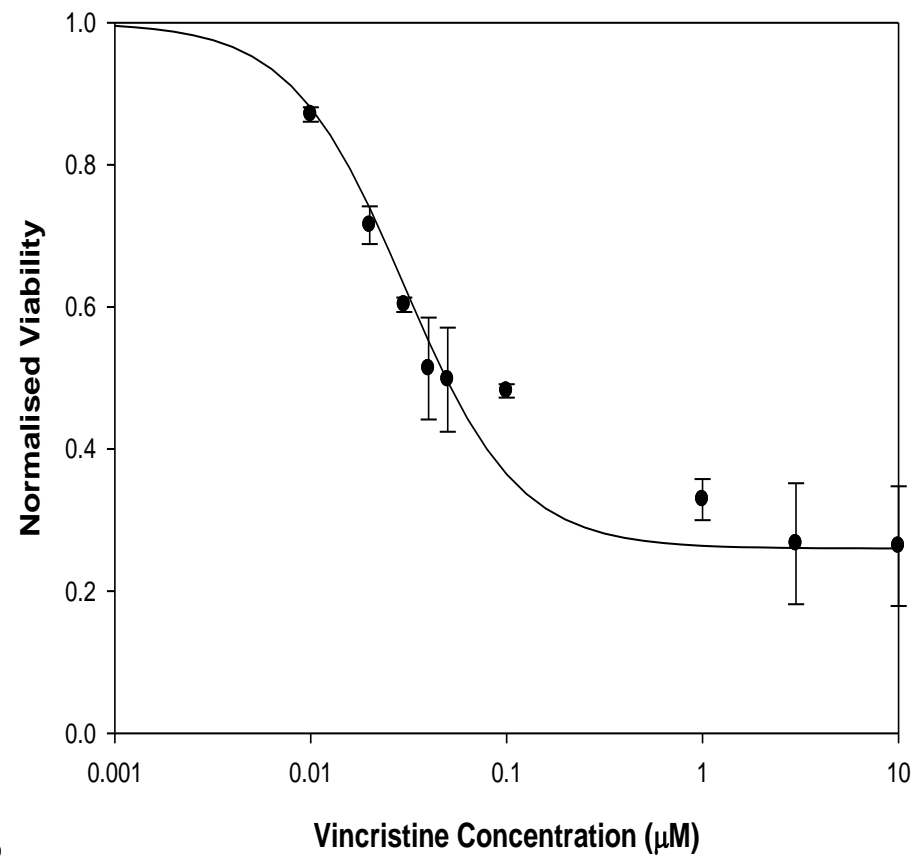

Figure 1 Viability of the A549 cells measured by MTT absorbance at 96 hours after exposure to vincristine. Error bars denote the standard error on the mean at each concentration.

85

\section{Interaction of vincristine with the nucleus of A549 cells}

To identify any biochemical changes caused by the direct 90 action of vincristine on the nucleus, the Raman spectra of the nucleus of A549 cells exposed to the range of concentrations of vincristine were recorded. The nuclear 
spectra of the mean control, and vincristine exposed samples are shown in Figure 2. The major changes observed in the spectra of the nucleus of A549 cells are in the Raman bands of the DNA bases, including thymine $5\left(669 \mathrm{~cm}^{-1}\right.$ and $\left.1253 \mathrm{~cm}^{-1}\right)$, adenine $\left(728 \mathrm{~cm}^{-1}\right)$, guanine $\left(1317 \mathrm{~cm}^{-1}\right)$ and cytosine $\left(783 \mathrm{~cm}^{-1}\right)$. These changes can be attributed to the action of the vincristine within the nucleus of the A549 cells and specifically due to interaction with the DNA. As the concentration of the drug exposure 10 increases, a decrease in the intensities of the bands associated with the DNA bases is observed. This is consistent with the results of the intercalation of the ethidium bromide, a well known DNA intercalator, into calf thymus DNA studied by Raman spectroscopy ${ }^{33}$.

${ }_{15}$ Conversely, ${ }^{21}$ have reported an increase in the intensities of the bands due to DNA bases while investigating the effect of very high concentrations, ranging from 200-300 $\mu \mathrm{M}$, of vincristine on calf thymus DNA, acellularly, with the help of FTIR spectroscopy. It should be noted, 20 however, that these concentrations are significantly higher than the maximum of the range employed in this study (10 $\mu \mathrm{M})$, and the clinically relevant $\mathrm{IC}_{50}(0.1 \mu \mathrm{M})$. The decrease in the intensities of the vibrational features ascribed to these DNA bases and most importantly the ${ }_{25}$ conformational changes of the B-form DNA into A-form, as indicated by the continuous decrease in the intensity of the Raman band at $827 \mathrm{~cm}^{-1}$ and concomitant increase in the intensity of the A-form DNA $\left(811 \mathrm{~cm}^{-1}\right)$, due to the action of vincristine, provides evidence of intracellular 30 intercalation of vincristine into the DNA. Moreover, in the control spectra of the nucleus of A549 cells, the $\mathrm{CH}_{2}$ scissoring mode, observed as a sharp band at $1422 \mathrm{~cm}^{-1}$, is considered as an important Raman marker of the B-form DNA and is found to be much more broader and lower in ${ }_{35}$ peak intensity in the A-form DNA ${ }^{34}$. This trend is clearly observable in the decreased contributions of this band in exposed samples in Figure 2, again indicating conformational changes in the B-form DNA in favour of the A-form.

40

Interestingly, in comparison to the effects on the nuclear Raman spectrum as a result of exposure to cisplatin, a known DNA groove binder, ${ }^{2}$, the changes observed in the conformation of the B-form of DNA, the dominant form of ${ }_{45}$ cellular DNA, are more prominent. These changes, including decreases in the Raman intensities of the bands due to DNA bases and changes in the DNA conformation are the important Raman markers of DNA intercalation ${ }^{33}$, 35-37. Changes in the phosphodiester linkages, the O-P-O ${ }_{50}$ stretching vibrations of the DNA, are also observed at $1095 \mathrm{~cm}^{-1}$ along with a shift towards lower wavenumber at the higher concentrations including 3 and $10 \mu \mathrm{M}$. These changes indicate that vincristine also has the ability to bind to the DNA externally, in addition to its insertion into the ${ }_{55}$ DNA helix ${ }^{21}$, as observed in the case of cisplatin studies ${ }^{2}$. Raman bands related to proteins are also observed, including those at $699 \mathrm{~cm}^{-1}$ and $718 \mathrm{~cm}^{-1}, 879 \mathrm{~cm}^{-1}, 1556$ $\mathrm{cm}^{-1}$ (tryptophan ring breathing), $1265 \mathrm{~cm}^{-1}$ (amide-III, $\alpha$ - helix), $1302 \mathrm{~cm}^{-1}\left(\mathrm{CH}_{2}\right.$ deformation), and $938 \mathrm{~cm}^{-1}$ (C-C 60 stretching), $959 \mathrm{~cm}^{-1}$ ( $\mathrm{CH}_{3}$ deformation) and $1060 \mathrm{~cm}^{-1}(\mathrm{C}-$ $\mathrm{N}$ stretching). The intensities of all these Raman bands increase as a result of an increase in the concentration of the exposures of the vincristine, particularly at the higher concentrations of this anticancer drug. This may be due to ${ }_{65}$ the fact that, after the conformational changes caused in the DNA by the anticancer drug binding, high mobility group proteins bind to the intercalation site and prevent repair by nuclease enzyme excision ${ }^{38}$. Furthermore, the proteins which are present in the nucleus, essentially ${ }_{70}$ required for the DNA strand packaging, may be more exposed due to the DNA strand opening which is caused by the intercalation of the vincristine.

It should be noted that the Raman spectral changes observed in Figure $\mathbf{2}$ and discussed above can not 75 unambiguously be attributed specifically to either the direct chemical binding of the vincristine to the DNA in the nucleus of the A549 cells or the subsequent physiological response of the cells to the drug. Therefore, PLS-Jack knifing was employed in an attempt to ${ }_{80}$ differentiate the chemical and the physiological effect of the drug by regressing the Raman spectral data from the nucleus of A549 cells against the exposure concentrations, compared to a similar regression against the cell viability end points ${ }^{2}$.

PLS-Jack knifing analysis was carried out on the Raman spectral data from the nucleus of control and exposed A549 cells (over the full dose range) to further understand and confirm the mode of action of vincristine as an 90 intercalative agent with DNA, and to identify the fingerprints of this interaction within the cellular spectra of exposed cells. The regression co-efficients were obtained by PLS-Jack knifing for separate regressions against vincristine concentrations and against the cell viability, as ${ }_{95}$ determined using the MTT assay. To reveal spectral changes that are most statistically significant with respect to regression against either endpoint, a t-test $(\mathrm{p}<0.001)$ was applied to the PLS-Jack knifing results, and the spectral features identified by this process are highlighted by 100 vertical bands in Figure 3. The spectral bands identified and their assignments are tabulated in the Supplementary Information. The PLS regression of the nuclear data against vincristine concentrations identified a number of spectral features, labelled in Figure $3 \mathbf{A}$, related to the 105 DNA bases, including guanine (1209-1211 $\mathrm{cm}^{-1}, 1289$ $\left.1309 \mathrm{~cm}^{-1}, 1320-1322 \mathrm{~cm}^{-1}\right)$, thymine $\left(673-678 \mathrm{~cm}^{-1}, 733-\right.$ $\left.737 \mathrm{~cm}^{-1}, 1251-1257 \mathrm{~cm}^{-1}, 1378-1381 \mathrm{~cm}^{-1}\right)$ and cytosine (773-778 $\left.\mathrm{cm}^{-1}, 1166-1173 \mathrm{~cm}^{-1}, 1298-1309 \mathrm{~cm}^{-1}\right)$. These features are identified only in the regression against the 110 concentration of the vincristine. Moreover, changes associated with the phosphodiester linkage, O-P-O of the DNA, are also highlighted (1062-1065 $\mathrm{cm}^{-1}$ and 1075-1090 $\mathrm{cm}^{-1}$ ), confirming the indications from Figure 2 that vincristine, in addition to the intercalation mode of action, 115 can also bind to the DNA externally. 
The changes which are observed only in the regression of the nuclear data against cell viability, Figure 3 (B), include C-C stretching of tyrosine residues $\left(637-643 \mathrm{~cm}^{-1}\right)$, tryptophan ring breathing $\left(696-700 \mathrm{~cm}^{-1}\right)$, amide-III (1250$\left.{ }_{5} 1256 \mathrm{~cm}^{-1}\right), \mathrm{CH}$ in plane bending of tyrosine $\left(842,844 \mathrm{~cm}^{-}\right.$ $\left.{ }^{1}, 1176-1177 \mathrm{~cm}^{-1}\right)$ and $\mathrm{CH}$ deformation $\left(1340-1343 \mathrm{~cm}^{-1}\right)$, which can be assigned to proteins. These features potentially originate from the high mobility group proteins which are activated to prevent further damage to the cell 10 and to repair by nuclease enzyme excision ${ }^{38}$.

Comparing the regression co-efficients obtained by PLSregression analysis of the Raman spectral data against the

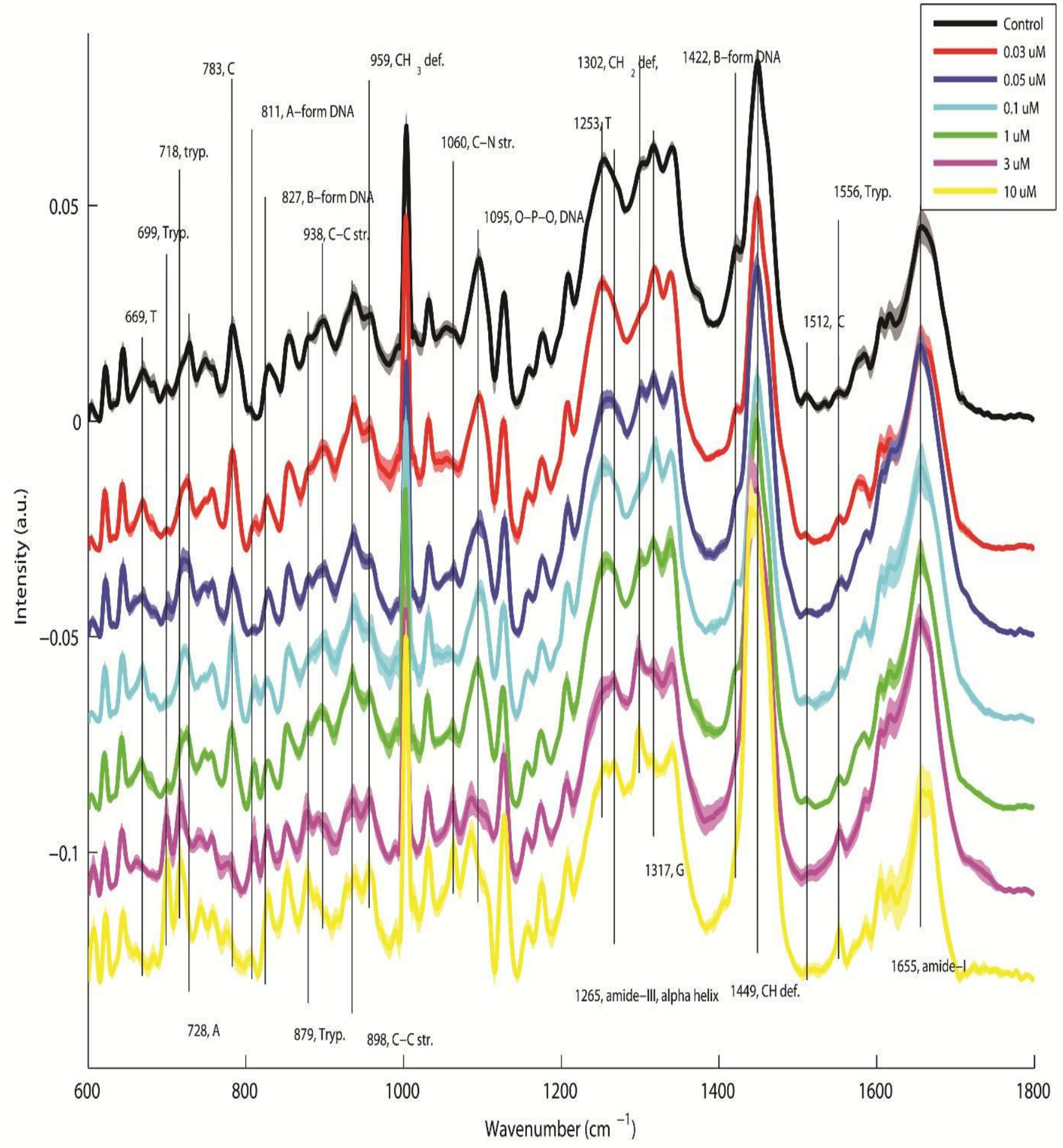

Figure 2: Mean spectrum of the nucleus of control and exposed A549 cells to 0.01-10 $\mu \mathrm{M}$ vincristine. 

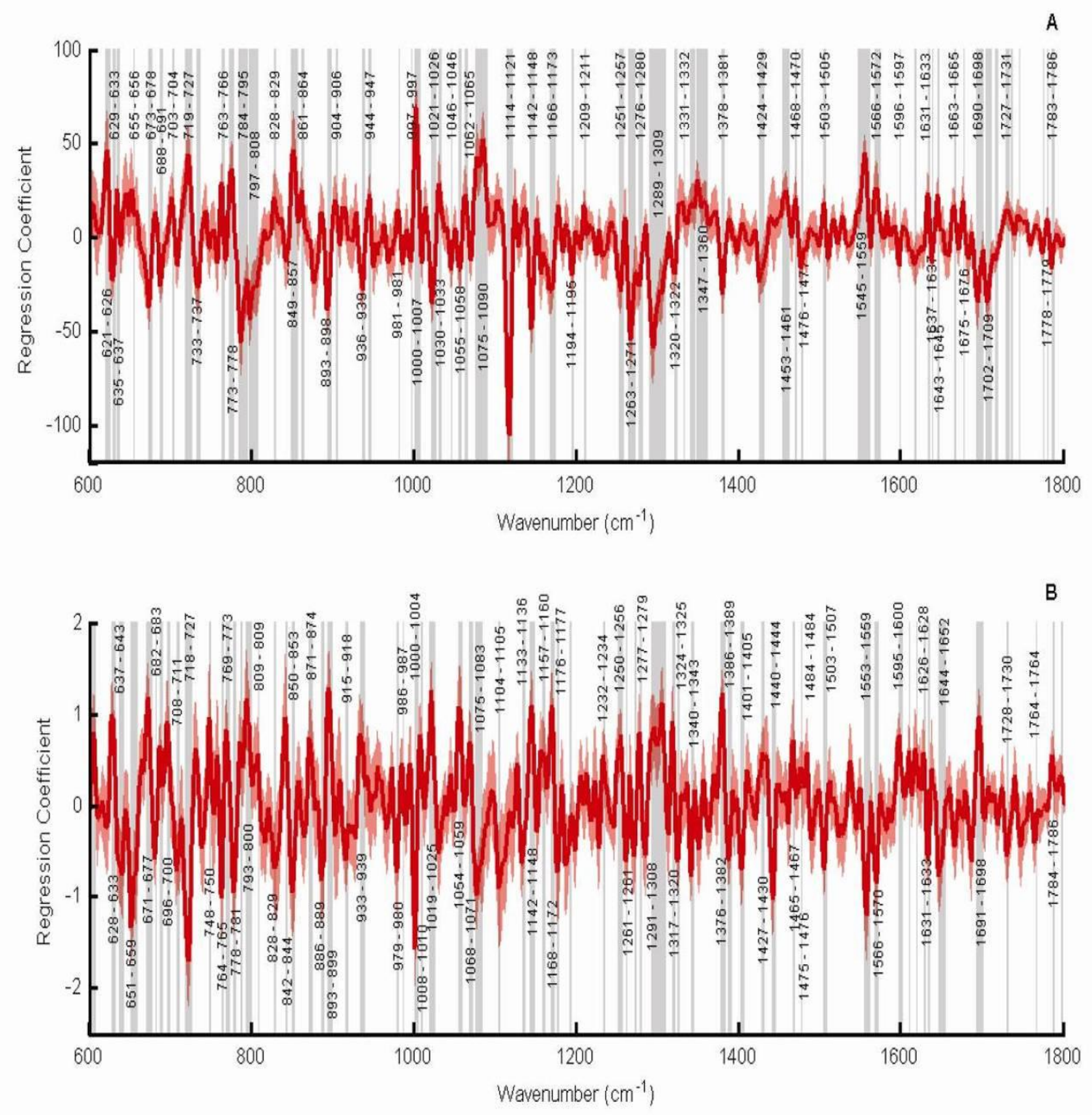

Figure 3 Feature selection in PLS-Jack knifing of Raman spectra of the A549 cell nucleus against (A) vincristine concentrations and (B) against cellular viability. The shaded areas in grey denote the statistically significant features selected using PLS Jack-knifing with a t-test $(p<0.001)$ of regression coefficients (shown in red with associated standard error shaded about them). This demonstrates that the spectral data contains features associated with the biochemical effect of vincristine on the nucleus (A) and the associated effect on cellular viability (B). 
concentrations of the exposures of the vincristine (which highlight the primary biochemical effect of the action of the agent) with those obtained via regression against cell viability (which highlight biochemical markers of the 5 change in the viability of the cell), very different spectral features are selected as being statistically significant. This allows the differentiation of the biochemical changes caused in the A549 cells due to the DNA binding of the vincristine from the physiological response of the cells. It 10 is noted that the PLS-Jack-knifing identifies a range of spectral features of relevance in the regression against each set of targets, the relevance of which appears statistically justified by the application of the t-test of the regression coefficients. Karaman et al. have however demonstrated 15 that, in comparison to Sparse PLSR, the PLS- Jack knifing method was prone to selecting uninformative variables ${ }^{39}$. Ultimately the accuracy, sensitivity and specificity of the method should be validated using simulated datasets ${ }^{12}$.

${ }_{20}$ It is also noted that as a function of concentration, the cells which remain alive and are therefore probed by CRM potentially include those which have not yet been exposed, or have not yet responded to the drug, at low concentrations and potentially cells which are immune at 25 higher concentrations. Nevertheless, the MTT assay is a measure of mitochondrial activity of the cell population, and the spectral markers identified by regression of the CRM data against the MTT target should provide a similar measure of this as an indication of viability for in vitro 30 screening, in a label free manner. Ideally, to examine the true cellular response, CRM should be performed on live cells with subcellular resolution in a time resolved fashion.

Expression of bcl-2 protein in A549 cells treated with ${ }_{35}$ vincristine analysed by Flow cytometry

Raman spectroscopic analysis of the nucleus of exposed cells clearly indicates the interaction of vincristine with nuclear DNA. The bcl-2 protein is an anti-apoptotic protein 40, 41 , and is involved in blocking DNA damage induced 40 apoptosis ${ }^{42,43}$. Changes in the expression of bcl-2 after exposure of the A549 cells to vincristine would indicate the involvement of the DNA damage pathway in the mode of action of the drug. Enhanced expression would point towards the development of resistance towards DNA ${ }_{45}$ damage induced cell death and decreased expression vice versa. Therefore, simultaneous observation of bcl-2 as a result of DNA damage and reduced cellular viability would point towards alternative mechanisms of cell death.

The results of flow cytometry for the expression of bcl-2 50 protein in A549 cells as a result of the treatment with various concentrations of vincristine ranging from 0.01 $\mu \mathrm{M}-10 \mu \mathrm{M}$, are shown in Figure 4. The results show that, due to the exposure of different concentrations of vincristine to A549 cells, the level of bcl-2 protein ${ }_{55}$ compared to control increases steadily up to a concentration of $5 \mu \mathrm{M}$, whereupon it decreases. These results indicate the involvement of the bcl-2 protein and therefore DNA damage in the mode of action of vincristine. A549 cells do not intrinsically express marked ${ }_{60}$ levels of bcl-2 protein as shown by ${ }^{23,44}$. The up-regulation of the bcl-2 protein is therefore a response of the cell to the external agent which causes damage to the nuclear DNA. A similar expression profile, up regulation followed by down regulation of the bcl-2 protein, was observed while ${ }_{65}$ studying the effect of the anaesthetic halothane, considered as a DNA damaging agent, on A549 cells and this expression profile has been reported to be responsible for the resistance to apoptosis at low doses, whereas induced apoptosis due to DNA damage becomes prominent upon 70 down regulation of bcl-2 at high doses ${ }^{23}$. In the current study, the Raman spectral data also indicates that vincristine binds to the cellular DNA by intercalation, so here bcl-2 up regulation may be in response to the DNA damage caused by the drug ${ }^{45}$. This may lead to the 75 conclusion that vincristine also binds to DNA by intercalation, causes up regulation of bcl-2, whose antiapoptotic function helps to delay the response of the cells at low doses (development of resistance). The bcl-2 expression is observed to decrease at doses > $5 \mu \mathrm{M}$, ${ }_{80}$ however, indicating that above these doses the cells are susceptible to apoptosis induced by DNA damage.

The Raman results give a clear indication that the documented acellular interactions of vincristine with DNA also occur intracellularly. However, the bcl-2 results ${ }_{85}$ indicate a resistance to apoptosis induced by DNA damage at vincristine doses $<5 \mu \mathrm{M}$. Critically however, this dose is significantly higher than the $\mathrm{IC}_{50}$ value of $0.10 \pm 0.03 \mu \mathrm{M}$, measured by the MTT assay. Therefore, the dominant mechanism of cell death at lower doses cannot be ascribed 90 to DNA damage, but rather to the mechanism of tubulin binding leading to a change in the dynamics of the microtubule assembly and prevention of the formation of bi-polar spindles ${ }^{18}$.

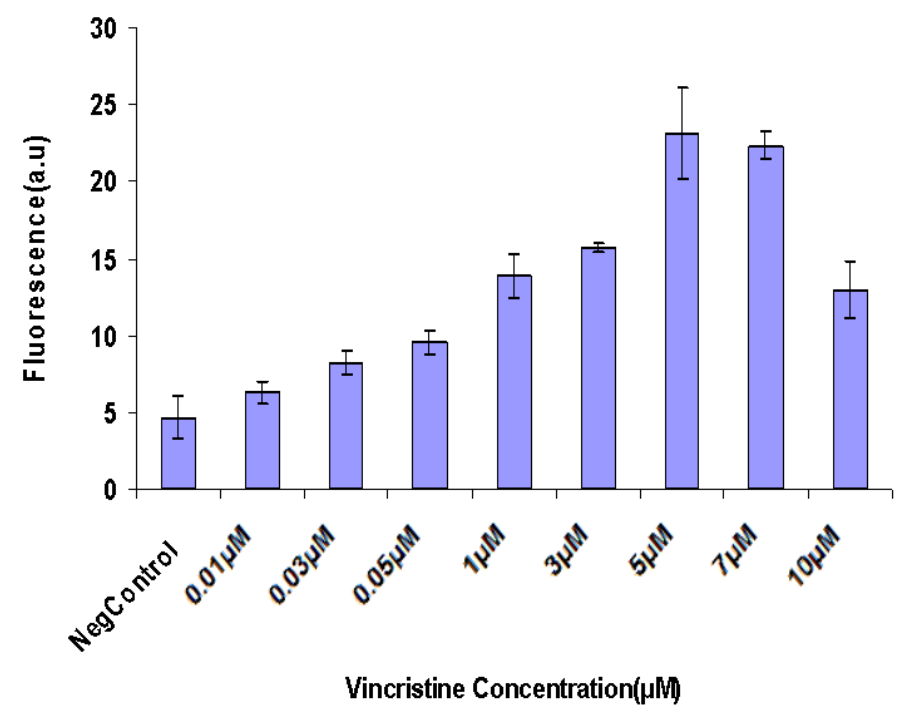

95

Figure 4 Expression level of bcl-2 shown as increase in the fluorescence, due to the treatment of different concentrations of vincristine in A549 cells determined by flow cytometry. 


\section{Conclusion}

The Raman analysis confirms that vincristine interacts with the nuclear DNA resulting in significant changes to the 5 spectroscopic markers of DNA which are characteristic of both intercalation and external binding. Changes observed in the DNA related features include those of cytosine (783 $\left.\mathrm{cm}^{-1}\right)$, guanine $\left(1318 \mathrm{~cm}^{-1}\right)$, thymine $\left(1375 \mathrm{~cm}^{-1}\right), \mathrm{O}-\mathrm{P}-\mathrm{O}$ of DNA $\left(1095 \mathrm{~cm}^{-1}\right)$. Notably, the changes in the B-form 10 DNA $\left(827 \mathrm{~cm}^{-1}\right)$ in favour of A-form conformation and Bform DNA $\left(1422 \mathrm{~cm}^{-1}\right)$ are prominent and systematic as a function of vincristine exposure. These changes can be taken as the Raman markers of DNA intercalation.

Expression of bcl-2 in A549 cells as a result of exposure to 15 vincristine is found to be concentration dependant and increases with increasing concentration to a maximum, whereafter levels are reduced at higher doses. The upregulation of bcl-2 is the response of the cell to the external agent which causes damage to the DNA and affects an 20 inhibition of apoptosis. In the current study, the Raman spectral data indicated that vincristine binds the cellular DNA by intercalation, so here bcl-2 up regulation is in response to the DNA damage caused by the drug and confirms the findings of the Raman study for the ${ }_{25}$ interaction of this drug with nucleus of the A549 cells. Nevertheless, the MTT assay clearly indicates loss of viability at these doses, pointing to microtubule damage as the primary mode of action in this region. The study demonstrates the potential of Raman spectroscopy, not ${ }_{30}$ only for the fingerprinting and screening of cellular responses but for the elucidation of mechanisms of action of external agents.

\section{${ }_{35}$ Acknowledgements}

The authors acknowledge funding through the Technology Sector Research (Strand III) programme of the Irish Higher Education Authority and the Irish HEA Programme for

${ }_{40}$ Research in Third Level Institutions, Cycle 4 National Biophotonics and Imaging Platform for Ireland (NBIPI), supported by the European Union Structural Fund.

\section{References}

45

1. C. A. Owen, J. Selvakumaran, I. Notingher, G. Jell, L. L. Hench and M. M. Stevens, Journal of Cellular Biochemistry, 2006, 99, 178-186.

$502 . \quad$ H. Nawaz, F. Bonnier, P. Knief, O. Howe, F. M. Lyng, A. D. Meade and H. J. Byrne, Analyst, 2010, 135, 3070-3076.

$3 . \quad$ H. Nawaz, F. Bonnier, A. D. Meade, F. M. Lyng and H. J. Byrne, Analyst, 2011, 136, 2450-2463.

4. F. M. Lyng, E. O. Faolain, J. Conroy, A. D. Meade, P. Knief,

55 B. Duffy, M. B. Hunter, J. M. Byrne, P. Kelehan and H. J. Byme, Experimental and Molecular Pathology, 2007, 82, 121129.

5. J. Chan, S. Fore, S. Wachsman-Hogiu and T. Huser, Laser

Photon. Rev., 2008, 2, 325-349.
$606 . \quad$ T. Huser, C. A. Orme, C. W. Hollars, M. H. Corzett and R. Balhorn, J. Biophotonics, 2009, 2, 322-332.

7. P. Knief, C. Clarke, E. Herzog, M. Davoren, F. M. Lyng, A. D. Meade and H. J. Byrne, 2009.

8. A. D. Meade, C. Clarke, F. Draux, G. D. Sockalingum, M. 65 Manfait, F. M. Lyng and H. J. Byrne, Anal. Bioanal. Chem., 2010, 396, 1781-1791.

9. A. D. Meade, F. M. Lyng, P. Knief and H. J. Byrne, Anal Bioanal Chem, 2007, 387, 1717-1728.

10. J. Dorney, F. Bonnier, A. Garcia, A. Casey, G. Chambers and 70 H. J. Byrne, Analyst, 2012, 137, 1111-1119.

11. F. Draux, P. Jeannesson, A. Beljebbar, A. Tfayli, N. Fourre, M. Manfait, J. Sule-Suso and G. D. Sockalingum, Analyst, 2009, 134, 542-548.

12. M. E. Keating, F. Bonnier and H. J. Byrne, Analyst, 2012, 137, $75-5792-5802$.

13. J. Ling, S. D. Weitman, M. A. Miller, R. V. Moore and A. C. Bovik, Applied optics, 2002, 41, 6006-6017.

$14 . \quad$ J. Y. Ling, Q. Z. Yang, S. S. Luo, Y. Li and C. K. Zhang, Chinese Chemical Letters, 2005, 16, 71-74.

$8015 . \quad$ I. Notingher, Sensors, 2007, 7, 1343-1358.

16. S. Verrier, I. Notingher, J. M. Polak and L. L. Hench, 2004.

17. Y. Yang, J. Sule-Suso, G. D. Sockalingum, G. Kegelaer, M Manfait and A. J. El Haj, Biopolymers, 2005, 78, 311-317.

18. L. Wilson and M. A. Jordan, Chemistry \& Biology, 1995, 2 $85 \quad 569-573$

19. Y. Zhu, H. Zeng, J. M. Xie, L. Ba, X. Gao and Z. H. Lu, Microscopy and Microanalysis, 2004, 10, 286-290.

$20 . \quad$ H. W. Tang, Y. Ye, T. Li, J. S. Zhou and G. Q. Chen, Analyst, 2003, 128, 974-979.

$9021 . \quad$ G. Tyagi, D. K. Jangir, P. Singh and R. Mehrotra, DNA and cell biology, 2010.

22. A. Beham, M. C. Marin, A. Fernandez, J. Herrmann, S. Brisbay, A. M. Tari, G. Lopez-Berestein, G. Lozano, M Sarkiss and T. J. McDonnell, Oncogene, 1997, 15, 2767-2772.

$9523 . \quad$ E. Stephanova, T. Topouzova-Hristova and R. Konakchieva, Toxicol In Vitro, 2008, 22, 688-694.

24. T. Mosmann, Journal of Immunological Methods, 1983, 65, $55-63$.

25. A. D. Meade, C. Clarke, F. Draux, G. D. Sockalingum, M.

100 Manfait, F. M. Lyng and H. J. Byrne, Anal Bioanal Chem, 2010, DOI: 10.1007/s00216-009-3411-7. F. Erubbs, Technometrics, 1969,11, 1-\&. H. Martens and M. Martens, 2000. A. D. Meade, H. J. Byrne and F. M. Lyng, Mutation ResearchReviews in Mutation Research, 2010, 704, 108-114. F. Westad and H. Martens, Journal of near Infrared Spectroscopy, 2000, 8, 117-124.

J. De Gelder, K. De Gussem, P. Vandenabeele and L. Moens, Journal of Raman Spectroscopy, 2007, 38, 1133-1147.

$11031 . \quad$ P. R. T. Jess, V. Garces-Chavez, D. Smith, M. Mazilu, L. Paterson, A. Riches, C. S. Herrington, W. Sibbett and K. Dholakia, Optics Express, 2006, 14, 5779-5791.

32. I. Notingher, S. Verrier, S. Haque, J. M. Polak and L. L. Hench, Biopolymers, 2003, 72, 230-240.

$11533 . \quad$ K. Yuzaki and H. O. Hamaguchi, Journal of Raman Spectroscopy, 2004, 35, 1013-1015.

34. G. J. Thomas, J. M. Benevides, S. A. Overman, T. Ueda, K Ushizawa, M. Saitoh and M. Tsuboi, Biophysical Journal, 1995, 68, 1073-1088.

$12035 . \quad$ J. M. Benevides, J. Kawakami and G. J. Thomas, Journal of Raman Spectroscopy, 2008, 39, 1627-1634.

36. J. M. Benevides and G. J. Thomas, Biochemistry, 2005, 44, 2993-2999.

37. M. Tsuboi, J. M. Benevides and G. J. Thomas, Biophysical 125

38. J. C. Huang, D. B. Zamble, J. T. Reardon, S. J. Lippard and A. Sancar, Proceedings of the National Academy of Sciences of the United States of America, 1994, 91, 10394-10398.

39. Ä. b. Karaman, E. M. Qannari, H. Martens, M. S. Hedemann,

130 K. E. B. Knudsen and A. Kohler, Chemometrics and Intelligent Laboratory Systems, 2013, 122, 65-77.

40. C. Borner, Molecular immunology, 2003, 39, 615-647. 
41. M. G. Vander Heiden and C. B. Thompson, Nature cell biology, 1999, 1, E209-216.

42. S. A. Park, H. J. Park, B. I. Lee, Y. H. Ahn, S. U. Kim and K. S. Choi, Brain research, 2001, 93, 18-26.

5 43. S. Singh, R. R. Chhipa, M. V. Vijayakumar and M. K. Bhat, Cancer Letters, 2006, 236, 213-221.
44.
H. K. Bojes, P. K. Suresh, E. M. Mills, D. R. Spitz, J. E. Sim and J. P. Kehrer, Toxicol Sci, 1998, 42, 109-116.
45. P. A. Sotiropoulou, A. Candi, G. Mascre, S. De Clercq, K. K. Youssef, G. Lapouge, E. Dahl, C. Semeraro, G. Denecker, J. C. Marine and C. Blanpain, Nature cell biology, 2010, 12, 572-U121.

\section{Supplementary information:}

15

Spectral ranges $\left(\mathrm{cm}^{-1}\right)$

621-626

629-633

635-637

637-643

655-656

673-678

696-700

703-704

708-711

719-727

733-737

$748-750$

763-766

769-773

773-778

784-795

$797-808$

828-829

842-844

849-857

861-864

893-898

904-906

936-939

944-947

1000-1007

\section{assignments}

C-C twisting of phenyl

C-C stretching

$\mathrm{C}-\mathrm{C}$ stretching

$\mathrm{C}-\mathrm{C}$ stretching of tyrosine residues

alanine

thymine

tryptophan ring breathing

tryptophan

tyrosine

Adenine/tryptophan

thymine

thymine

thymine

alanine

tryptophan

cytosine

O-P-O of DNA (A-form)

$\mathrm{O}-\mathrm{P}-\mathrm{O}$ of DNA (B-form)

$\mathrm{CH}$ in plane bending of tyrosine

$\mathrm{C}-\mathrm{C}$ stretching

tryptophan

Deoxiribose of DNA

valine

C-C stretching

valine

Phenyl alanine 
1021-1026

1030-1033

1055-1058

1062-1065

1075-1090

1114-1121

1142-1148

1166-1173

1176-1177

1194-1196

1209-1211

1251-1257

1250-1256

1261-1261

1263-1271

1276-1280

1289-1309

1320-1322

1331-1332

1347-1360

1340-1343

1378-1381

1424-1428

1453-1461

1468-1470

1503-1505

1545-1559

1566-1572

1596-1597

1631-1633

1643-1645

1663-1665
$\mathrm{CH}$ in plane bending

$\mathrm{CH}$ in plane bending

C-N stretching

$\mathrm{O}-\mathrm{P}-\mathrm{O}$ of the DNA

$\mathrm{O}-\mathrm{P}-\mathrm{O}$ of the DNA

C-N stretching

C-C stretching

cytosine

$\mathrm{CH}$ in plane bending of tyrosine

tyrosine

guanine

thymine

amide-III

Amide-III $\beta$-sheet

Amide-III $\beta$-sheet

Amide-III $\alpha$-sheet

cytosine

guanine

tryptophan

$\mathrm{CH}_{3}$ stretching

$\mathrm{CH}$ deformation

thymine

$\mathrm{CH}$ deformation

$\mathrm{CH}$ deformation

histidine

$\mathrm{C}=\mathrm{C}$ stretching

tryptophan

tryptophan

$\mathrm{C}=\mathrm{C}$ bending

histidine

$\mathrm{C}=\mathrm{C}$ stretching

amide-I 
1702-1709

1727-1731

1783-1786 thymine

$\mathrm{C}=\mathrm{O}$ ester

$\mathrm{C}-\mathrm{C}$ bending 